\title{
Development Communication in monitoring and Media Cooperation (Study on Development Coverage of Bangka Regency Government in Local Print Media)
}

\author{
Suryani ${ }^{1}$, Septiar Andrilaransyah ${ }^{2}$ \\ \{suryani@stisipolp12.ac.id ${ }^{1}$, septiarandrilaransyah@gmail.com² ${ }^{2}$, \\ STISIPOL Pahlawan12 Sungailiat Bangka, Indonesia ${ }^{1}$, STISIPOL Pahlawan12 \\ Sungailiat Bangka, Indonesia ${ }^{2}$
}

\begin{abstract}
To understand the government in development communication through mass media and its implications for media cooperation policy, it is necessary to describe in mixed methode. In this study, it was found that based on the intensity of the news, Rakyat Pos (45\%) were the most intensive in covering development issues compared to Bangka Pos (30\%) and Babel Pos (25\%). In the third column, the newspapers ranked news based on closeness $(90 \%)$ compared to the main page $(10 \%)$. Meanwhile, from the technical aspect of writing, straight news is the main choice $(100 \%)$. Issues of development administration (57\%) more attractive than issues of governance (43\%). Based on resource persons, bureaucrats are most frequently quoted (96\%). Furthermore, neutral $(58 \%)$ and positive $(35 \%)$ news tones are more dominant. The implication of reporting on cooperation policies is not a reference in media selection, and their hope is that the media can carry out their idealism.
\end{abstract}

Keywords: Development Communication, Newspapers, Monitoring, Cooperation

\section{Introduction}

The government of Bangka Regency in carrying out development must involve the participation of the community as its stakeholders. Because the development carried out must provide benefits for the welfare of the community and build a people's economy that supports regional development. The involvement of community participation must of course be supported by providing access to information on all development program activities and local government administration, either directly or indirectly, facilitated by various existing communication media.

Establishing cooperation with the media is carried out with the hope that all information on the administration of government administration and development is conveyed clearly and ultimately will lead to public understanding of every step taken by the local government.

Collaboration with the media (media relations) [1]. is a public relations communication activity to establish understanding and good relations with the mass media in order to achieve maximum and balanced organizational publications. As former University of Wisconsin-River Fall Public Relations Officer Barbara Averill (1997) put it, "media relations is only one part of public relations, but it can be a very important and efficient tool. Once we can formulate 
messages that are not only accepted but also considered important by the local media, then we have already made big strides towards the success of the program [2].”

In establishing a relationship with the media, the Public Relations of the Bangka Regency Government is required to be skilled in shaping the perceptions of the media crew towards the institution and giving value to these relationships in getting as much publicity as possible from the media. Launching new programs as well as important information relating to policies urgently requires the role of the mass media.

The mass media has the power to form public opinion or what is commonly called public opinion. According to Leonard W. Doob, public opinion is the attitude of people about something, where they are members of the same society. This definition states that public opinion is closely related to human attitudes, namely attitudes personally and as group members. Doob further revealed that what shapes public opinion is a person's personal attitude or the attitude of his group, because attitudes are determined by experiences, namely experiences from and within the group as well [3].

The collaboration with 29 media which is carried out in the form of publications on government administration and the development program of the Bangka Regency Government and advertisements is certainly expected to form the brand image of the Bangka Regency Government which then creates a good reputation in the eyes of the community and its stakeholders. The reputation created through this publicity needs to be evaluated.

Where media relations can be said to be successful when the mass media provides feedback in the form of news. To determine this success, it is necessary to do media monitoring with the aim of dissecting the news carried out by the mass media. In addition, media monitoring is also useful to help determine policy making and is an important activity for a public relations officer.

Meanwhile, the edition chosen as research material was December 2019. The selection of the periodization was based on the assumption that even one more year of the elected Bangka Baru District Head was elected for the 2018-2023 period, the pair Mulkan and Syahbudin $(26 / 09 / 2018)$, and in the December issue, there are important events which are flashbacks from the previous news. In addition, limited time and energy do not allow analysis of all district government news. Bangka in one year. During the period December 2019, there were 167 news items released by the three newspapers, namely Bangka Pos with 50 news, Babel Pos with 42 news and Rakyat Pos with 75 news, for details, see the chart below

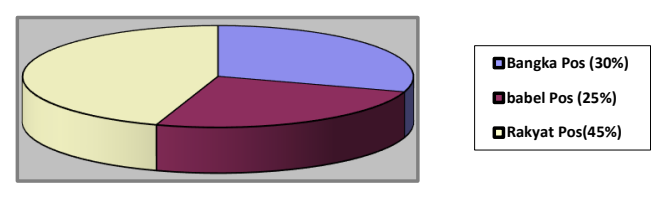

Figure 1. Development Communication news on December 2019

The focus of this research is: (i) how the news of three Bangka Pos, Babel Pos and Rakyat Pos newspapers on the development communication of bangka regency government in December 2019 priode. (ii) how the implications of the news on media cooperation policy in Bangka Regency

The purpose of this research is to describe media monitoring of development communications of Bangka Regency Government through content analysis and implications 
of the news to the policy of cooperation conducted with all three local newspapers in Bangka Belitung Province.

It is hoped that this research will be useful all interested parties by providing : (i) academic benefits, by expanding the development of knowledge and providing references for future research; (ii) Practical benefits, newspaper editors can further increase the resources of journalists so that in framing news in accordance with journalistic rules and for local governments to be able to prepare complete data for junalis so that they can frame news more comprehensively, and (iii) social benefits, through this research helps the Indonesian people to understand the management of media and media cooperation systems conducted by local governments so that the public can be more media literate in the face of information attacks.

\section{Literature Review}

\subsection{Development Communication}

Development communication comes from two words, namely communication and development. simple communication means the process of exchanging messages between the communicator (sender) and the communicator (recipient). While development according to Rogers and Soemaker is a type of social change where new ideas are introduced in a social system to generate per capitla income and higher levels of life through more modern production and better social organization.[4]. .According to Peterson (2000) [5] development communication is an organized effort to use communication processes and media in improving social and economic standards, which generally take place in developing countries. Similarly, Quebral (1973) says development communication is a communication done to carry out the development of a country. Where as according to Widjaja A. W. defines them quite differently, that is, he interprets that development communication as a communication containing the messages of development.

From the above description, it can be concluded that development communication is a discipline and communication practice in the context of developing countries and is done for planned social change. Development communication is intended to consciously improve humane development and be carried out both directly and in media[6].

\subsection{Development Journalism}

Development communication requires mass media in the delivery of messages. The media used should be fast cheap and mass. Therefore, a model is needed to formulate how to deliver the message of development quickly cheaply and mass, then came the term development journalism.[7]. In essence, development journalism discusses $h$ ow the media plays a role in disseminating development information. Development information does not only cover physical development. But such non-physical development like a morals, behavior ect. must also be conveyed by the mass media.

Definition of development journalism is the coverage of development as a process rather than as the development event. The emphasis of development news is not on the events of a particular moment, but rather on what happens to that particular priode, received and responded to by the public, impact of resulting in a long-term process of sustainable social and economic change [4].

The character of development news consists of three things namely (i), paying attention to the relevance of a development project with national needs and especially local needs; (ii) 
paying attention to the difference between the program plan and implementation; (iii) paying attention to the difference between the perceived impacts of society. The function of mass media in development according to Schramm [8], i.e.: (i), informs about national development, focuses their attention on the need to change, opportunities to cause change, methods and ways of causing change and if possible increasing aspirations; (ii), public helped participate in the decision-making process, expand dialogue and keep information flowing both upwards and downwards; and (iii), educating people to have skills.

and (iv), creating a constructive atmosphere, through newspapers and other mass media can be disseminated information to the public. Newspapers can broaden the horizon of thought and build sympathy, focusing development goals so as to create a compatible and effective development atmosphere.

Mass media according to Rachmadi (1989) [9], having a duty as one of the agents of change in development, is to: (i), expand the horizon of view, through the newspaper people know the events that occurred in other countries. (ii), focusing the public's attention on the messages it writes. In modern society, images of neighborhoods far from them are obtained from newspapers and other mass media. (iii) foster aspirations. With the mastery of media, a society can change their lives by imitating what the media conveys; and (iv), creating a constructive atmosphere, through newspapers and other mass media can be disseminated information to the public. Newspapers can broaden the horizon of thought and build sympathy, focusing development goals so that it wil be effective..

\subsection{Development News}

According to Ishadi Sutopo KS,[10], there are 12 categories of development news, i.e.: (i), government and administrative reformation, in this category are government activities. Inauguration of government officials, bureaucratic reform etc; (ii), food production, agricultural development and irrigation; (iii), development, mining and crude oil production; (iv)communication, transportation and tourism; (v), trade; (vi), labor and transmigration; (vii), regional and rural development; (viii), education and culture; (ix), public health; (x), mass media; (xi), law and law enforcement; and (xii), defense and national security.

\subsection{Media Relations}

Media relations is a public relations activity with the intention of conveying communication messages about institutional or companies activities, products, and all activities that need to be published through cooperation with the mass media to create publicity and positive image. With the mass media publisity, the company gets a positive image and at the same time the mass media gets the news [11].

The benefits of media relations are, i.e. : (i) building an understanding of the duties and responsibilities of corporations and mass media; (ii) build reciprocal trust with the principle of mutual respect and trust; (iii) accurate and trust information for the public [12].

\subsection{Media Monitoring}

Media monitoring is widely used in to conduct tracking or publicity searches conducted by public relations. The history of media monitoring began in the middle $1800 \mathrm{~s}$ as a media clipping service. Media clipping services (called "cutting media" in Europe) employees who work as readers, are deployed to scan articles in print news publications in search of the keywords of some clients. Similarly, kennedy [13] that it is important to note the use of media to relate to the target of the message, whether the message is addressed to the personal, the 
group, or the masses. The term monitoring is defined as surveillance or monitoring, more complete explanation of media monitoring is the process of reading, watching or listening with the editorial content of media sources, and then, identifying, storing and analyzing content containing certain keywords or topics.

\subsection{Policy}

The policy according to Thomas R. Dye is as everything the government does, why they do, and the results that make a life together appear different. And government policy is a process of how joint decisions on various public issues are formulated, implemented, evaluated and responded to by the public. The process from formulation to public response is referred to as a policy cycle. The policy cycle according starts from the identification of issues, implementation and evaluation of the policy impacts followed by policy feedback and so on this feedback again becomes part of identifying these issues, [14]

\subsection{Operational Definition}

The content of the news about the Bangka Regency Government is the administration and the implementation of development carried out by the Bangka Regency Government. There is a pattern of the news with categorization of the presentation format in the newspaper divided by the rublikasi space, the theme of the news or issue, the source of information and the tone of news.

\section{Methods}

This research methodology will be conducted using a mixed research method, with a quantitative descriptive content analysis approach as one of the scientific research techniques aimed at knowing the characteristics of the content and interesting inference of the content. Content analysis is intended to identify objectively, validly, realiabelly and can be replicated. Furthermore, using qualitative descriptive analysis research methods because this approach is best able to make observations in natural and social settings.

\subsection{Analysis Unit and Research Focus}

The quantitative content analysis unit used is: (i), the sample unit used is all news related to the Government. Bangka in three Bangka Pos, Babel Pos and Rakyat Pos in December 2019; (ii), the recording unit consists of thematic units, physical units and referential units; and (iii), the context unit uses all studies of theories related to this research object, so that the data generated by the recording unit has meaning. While the focus of this qualitative research is how the news implications of development communication to the media cooperation policy conducted by the Bangka Regency Government.

\subsection{Research Locations}

This research will be conducted in three local newspapers, namely Bangka Pos, Babel Pos and Rakyat Pos as well as the Department of Communication, Informatics and Statistics of Bangka Regency.

\subsection{Determination of Research objects and Subjects (Informants)}


To get accurate information, there are several criteria to consider, such as research objects determined by population and sample draw. The population is the news of three newspapers in December 2019 priode, a total of 167 news communication development government. Bangka, look at table below:

Table 1. Population

\begin{tabular}{llcccc}
\hline No & $\begin{array}{c}\text { Time } \\
\text { Range }\end{array}$ & $\begin{array}{c}\text { Bangka } \\
\text { Pos }\end{array}$ & $\begin{array}{c}\text { Babel } \\
\text { Pos }\end{array}$ & $\begin{array}{c}\text { Rakyat } \\
\text { Pos }\end{array}$ & Amount \\
\hline 1. & The first week & 9 & 13 & 29 & 51 \\
2. & The secon week & 15 & 16 & 23 & 54 \\
3. & The third wek & 12 & 6 & 10 & 28 \\
4. & The fourth week & 14 & 7 & 13 & 34 \\
& & 50 & 42 & 75 & $\mathbf{1 6 7}$ \\
\hline
\end{tabular}

Furthermore the sampling in this study uses the slovin formula, with the following formula: $\mathrm{n}=\mathrm{N} /\left(1+\left(\mathrm{N} \mathrm{x} \mathrm{e}^{2}\right)\right)$, description: $\mathrm{n}=$ number of elements/sample members $\mathrm{N}=$ number of elements/population members $\mathrm{e}=$ error level.

The population contained in this study was 167 news and the specified precision or significance level of 0.05 , then the size of the sample in this study was: $n=N /\left(1+\left(\mathrm{N} \mathrm{x} \mathrm{e}^{2}\right)\right) \mathrm{n}$ $=167 /(1+167(0.05) 2 \mathrm{n}=117,83$, so the overall number of news stories in the study was 118 news, and sampling was done through random sampling techniques, look at table below:

Table 2. Sampling

\begin{tabular}{llcc}
\hline No & Time Range & Sample & Amount \\
\hline 1. & The first week & $51 \times 118 / 167$ & 36 \\
2. & The secon week & $54 \times 118 / 167$ & 28 \\
3. & The third wek & $28 \times 118 / 167$ & 30 \\
4. & The fourth week & $34 \times 118 / 167$ & 24 \\
& & & 118 \\
\hline
\end{tabular}

Furthermore qualitatively the subject of this study is the person who is considered to know the most about the information required of the research object, so it will be easier for the researchers to track the activity that is being studied. The subject of this research are the Head of The Office of Communication, Informatics and Statistics of Bangka And Public Relations of the Bangka Government conducts media monitoring activities and media cooperation.

\subsection{Data Collection Techniques}

The data collection techniques used in this study are; (i) direct observation of newspaper clippings through coding sheet and public relations management process. The reason researchers make observations is to present a realistic picture of behavior or events, to answer questions, to help understand human behavior, and to evaluate what to include in conclusions. (ii) interviews conducted in this study use semi-structured interviews, asking questions from data sources. (iii) Documentation, researchers will search for data in the form of documents from interested parties. 


\subsection{Types of Data Sources}

Types of data sources obtained are from two sources: namely primary and secondary data sources. Primary data are obtained through coding sheet and interviews with researchers, Secondary data are obtained by researchers through supporting documents related to the research.

\subsection{Data Analysis Techniques}

In the data analysis stage, the data that has been collected through the coding process are then organized into several categories displayed in the form of tables and graphs. And then analyzed with statistical formula, $\mathrm{P}=\mathrm{f} / \mathrm{n} \times 100 \%$. Then will be done qualitative data analysis that is through the process of collecting data in the field, then the data is selected, grouped and compiled and conclusions drawn.

\subsection{Data Validity and Reability}

The validity of the data in this study uses the validity of quantitative and qualitative data, i.e.: (i), quantitative validity data in this study using the validity of the content which is the extent to which the measuring instrument fully shows all the categories that want to be viewed [15]. The validity of content is a validity estimated through testing of the feasibility or relevance of the test contents through rational analysis by expert judgement and measured by aiken formula $: \mathrm{V}=\sum \mathrm{s} /[\mathrm{n}(\mathrm{c}-1)], \mathrm{S}=\mathrm{r}-\mathrm{lo}(\mathrm{Lo}=$ lowest validity assessment number, $\mathrm{C}=$ highest validity assessment number and $\mathrm{R}=$ number). Then it will be measured the reability of the data using the Formula Ole R. Holsty, i.e. $2 \mathrm{M} / \mathrm{N} 1+\mathrm{N} 2$ ( $\mathrm{M}=$ same number of coding, $\mathrm{N}=$ number of coding created by coder), [16]

\section{Result and Discussion}

In this study, it was found that based on the intensity of the news, Rakyat Pos (45\%) were the most intensive in covering development issues compared to Bangka Pos $(30 \%)$ and Babel Pos (25\%). In the third column, the newspapers place news based on closeness $(90 \%)$ compared to the main page (10\%), meaning that almost the average development news of the district government. Bangka placed in a special area, for details see table below:

Table 3. Rublication

\begin{tabular}{llccccc}
\hline No & \multicolumn{1}{c}{ Rublication } & $\begin{array}{c}\text { Bangka } \\
\text { Pos }\end{array}$ & $\begin{array}{c}\text { Babel } \\
\text { Pos }\end{array}$ & $\begin{array}{c}\text { Rakyat } \\
\text { Pos }\end{array}$ & Amount & Percent \\
\hline 1. & Main page & 0 & 0 & 3 & 3 & 2,5 \\
2. & Tribun Babel & 1 & 0 & 0 & 1 & 0,1 \\
3. & Sungailiat Region (Hal. & $22 / 7$ & 0 & 0 & 29 & 25 \\
& 16/20) & & & & & \\
4. & Tribun Buffer & 5 & 0 & 0 & 5 & 4 \\
5, & Jagur & 0 & 2 & 0 & 2 & 1 \\
6. & Bangka & 0 & 36 & 0 & 36 & 30 \\
7. & Berita Bangka & 0 & 0 & 40 & 40 & 33 \\
8. & Lintas Babel & 0 & 0 & 1 & 1 & 0,1
\end{tabular}




\begin{tabular}{llcccc} 
9. Sambungan & 0 & 0 & 1 & 1 & 0,1 \\
Total & 35 & 38 & 45 & 118 & 100 \\
\hline
\end{tabular}

The use of small column sizes $<30 \mathrm{~cm} /$ column in the layout dimension tends to be an option (100\%). Meanwhile, from the technical aspect of writing, straight news is the main choice $(100 \%)$. News written in the straight news / hard news model uses a small column size, and this usually has short, concise material (Santana in Eko, 2006: 66). Such news is clearly not enough to raise awareness and mobilize the public to understand policy and development issues, for details see tabel below:

Table 4. Column Size

\begin{tabular}{llccccc}
\hline No & Column & $\begin{array}{c}\text { Bangka } \\
\text { Pos }\end{array}$ & $\begin{array}{c}\text { Babel } \\
\text { Pos }\end{array}$ & $\begin{array}{c}\text { Rakyat } \\
\text { Pos }\end{array}$ & Amount & Percent \\
\hline 1. & $5-10 \mathrm{~cm}$ & 15 & 14 & 26 & 55 & 46 \\
2. & $11-20 \mathrm{~cm}$ & 11 & 16 & 14 & 41 & 35 \\
3. & $21-30 \mathrm{~cm}$ & 9 & 8 & 5 & 22 & 19 \\
& & 35 & 38 & 45 & 118 & 100 \\
\hline
\end{tabular}

Issues of development administration (57\%) are more attractive than issues of governance (43\%). Based on informants, bureaucrats are most frequently quoted $(96 \%)$, followed by mass organizations (3\%), and politicians $(2 \%)$. Reports that touch the interests of many people are still interesting and sources who are considered capable of talking about development are bureaucrats, especially regents and their staff, for details see tabel below:

Table 5. Issues of News

\begin{tabular}{llccccc}
\hline No & \multicolumn{1}{c}{ Issues } & $\begin{array}{c}\text { Bangka } \\
\text { Pos }\end{array}$ & $\begin{array}{c}\text { Babel } \\
\text { Pos }\end{array}$ & $\begin{array}{c}\text { Rakyat } \\
\text { Pos }\end{array}$ & Amount & Percent \\
\hline 1. & $\begin{array}{l}\text { Development } \\
\text { administrations }\end{array}$ & 17 & 15 & 19 & 51 & 43 \\
2. & & & & & \\
& Governance & 18 & 23 & 26 & 67 & 57 \\
\hline
\end{tabular}

Table 6. Sources

\begin{tabular}{llccccc}
\hline $\mathbf{N}$ & \multicolumn{1}{c}{ Sources } & $\begin{array}{c}\text { Bangk } \\
\text { a Pos }\end{array}$ & $\begin{array}{c}\text { Babe } \\
\text { l Pos }\end{array}$ & $\begin{array}{c}\text { Rakya } \\
\text { t Pos }\end{array}$ & $\begin{array}{c}\text { Amoun } \\
\text { t }\end{array}$ & $\begin{array}{c}\text { percen } \\
\mathbf{t}\end{array}$ \\
\hline 1. & Bureaucrats & 34 & 38 & 41 & 113 & 96 \\
2. & Intellectual & 0 & 0 & 0 & 0 & 0 \\
3. & politicians & 0 & 0 & 2 & 2 & 2 \\
& Public figure & 0 & 0 & 0 & 0 & 0 \\
& Army/Police/Prosecut & 0 & 0 & 0 & 0 & 0 \\
& or & 1 & 0 & 2 & 3 & 2 \\
& mass organizations & 0 & 0 & 0 & 0 & 0 \\
& Private & 0 & 0 & 0 & 0 & 0 \\
& Community & 0 & 0 & 0 & 0 & 0
\end{tabular}


Furthermore, the trend of neutral (58\%) and positive $(35 \%)$ news tones is more than negative (7\%). It can be seen that even though the regional government has collaborated, the media are not shackled to carry out their role as social control that has idealism for things that are not in accordance with the rules and norms. Although on the other hand, press institutions have commercial needs as profit institutions, for details see tabel below:

Table 7. Tones of News

\begin{tabular}{llccccc}
\hline No & Tones & $\begin{array}{c}\text { Bangka } \\
\text { Pos }\end{array}$ & $\begin{array}{c}\text { Babel } \\
\text { Pos }\end{array}$ & $\begin{array}{c}\text { Rakyat } \\
\text { Pos }\end{array}$ & Amount & Percent \\
\hline 1. & Positive & 17 & 8 & 17 & 42 & 35 \\
2. & Negative & 2 & 2 & 4 & 8 & 7 \\
3. & Neutral & 16 & 28 & 24 & 68 & 58 \\
\hline
\end{tabular}

The implication of reporting on cooperation policies is not a reference in media selection, and they hope that the media can carry out their idealism optimally. This was revealed by the Head of the Communication, Informatics and Statistics Office of Kab. Bangka, Mr. Zulkarnaen Idrus and Bangka Regency Public Relations. Mr. Doddy Rinaldy

According to them, the need to communicate with the community cannot only be done directly, but also using the media. His party realizes that partnering with the media is very important so that the media can understand the dynamics in local government, so that the publication of development communications will have the expected effect, namely at the level of changes in knowledge, attitudes and behavior.

\section{Conclusion}

From the results of content analysis and interviews with sources, it can be concluded that the three local newspapers are considered sufficiently successful in creating a good reputation of local government, although the news written is not in-depth and comprehensive. But all activities carried out by the local government of Bangka Regency are conveyed to the public. As for cooperation policy with the media, do not look at how the media framed the communication development of Bangka Regency. but more to foster good relations and the results are expected to get positive publication.

\section{References}

[1] D. Wardhani, "Media Relations: Sarana Membangun Reputasi Organisasi," Yogyakarta Graha Ilmu, 2008.

[2] I. Yosal, "Media Relations Konsep, Pendekatan, dan Praktik," Bandung: Simbiosa Rekatama Media, 2008.

[3] S. Soemirat and E. Ardianto, Dasar-dasar public relations. Remaja Rosdakarya, 2002.

[4] S. Dilla, "Komunikasi Pembangunan pendekatan terpadu," Bandung: Simbiosa Rekatama Media, 2007. 
[5] D. Mulyana, Ilmu komunikasi: suatu pengantar. Remaja Rosdakarya, 2000.

[6] R. Harun and E. Ardianto, Komunikasi pembangunan \& perubahan sosial: perspektif dominan, kaji ulang, dan teori kritis. Rajawali Pers, 2011.

[7] H. Kusumaningrat and P. Kusumaningrat, "Jurnalistik Teori \& Praktik," Bandung PT Remaja Rosdakarya, 2009.

[8] J. Amri, "Komunikasi Massa dan Pembangunan Pedesaan," Jakarta: Gramedia Pustaka Utama, 1993.

[9] E. Kurniawan, "Studi analisis isi pemberitaan media massa tentang lingkungan hidup dan implikasinya terhadap kebijakan pengelolaan lingkungan di Kabupaten Bangka [Tesis]," 2006.

[10] D. M. Flournoy, Content analysis of Indonesian newspapers. Gadjah Mada University Press, 1992.

[11] R. Ruslan, "Public Relations Management \& Media Communications, Conception and Applications," Jakarta Rajawali Pers, 2008.

[12] F. Nova, Crisis public relations: bagaimana PR menangani krisis perusahaan. Grasindo, 2009.

[13] J. E. Kennedy and R. D. Soemanagara, "Marketing Communication: Taktik dan Strategi," Jakarta PT Bhuana Ilmu Pop., 2006.

[14] R. Martini, "Sosiologi Pemerintahan," 2011.

[15] Eriyanto, Analisis isi: Pengantar metodologi untuk penelitian ilmu komunikasi dan ilmu-ilmu sosial lainnya. Kencana Prenada Media Group, 2011.

[16] H. Retnawati, Heri Retnawati 9786021 547984. Yogyakarta: Parama Publishing, 2016. 